\title{
Principals' Perception of Globalization and its Influence on the Management of Secondary Education in Enugu State, Nigeria
}

\author{
Chukwu Leo C. \\ Enugu State University of Science and Technology, \\ Nigeria
}

\begin{abstract}
The study examined principals' perception of globalization and is influence on the management of secondary education in Enugu state, Nigeria. Three research questions and three null hypotheses guided the study. The research questions were answered using mean and grandmean scores, while the hypotheses were tested using t-test statistics at .05 level of significance. Survey research design was adopted for the study using an 18-item instrument tagged; impact of globalization questionnaire (IGQ). The instrument was developed by the researcher. The population for the study comprised of all 291 principals of all the 291 public secondary schools in Enugu state. 82 of the principals were female, while 209 were male. There was no sampling because the population was small and manageable. Following data analysis, findings revealed that; globalization has to a little extent influenced secondary education in Enugu state in the areas of teaching methods, instructional materials utilization and discipline. Recommendations include; better funding of secondary education, provision of requisite facilities and equipment in the various schools among others.
\end{abstract}

\section{Introduction}

We live in a rapidly changing world where communication continues to influence all aspects of our lives. A few years ago, interpersonal communication as well as inter organizational cum intra organizational communication was largely through posted letter writing as well as analogue telephony. Today the revolution in communication systems has made the world a global village. This means that with interconnectivity and internet systems, the posted communication that used to take days, weeks and even months to accomplish could come by within seconds via the touch of a bottom. Globalization through information communications technology (ICT) has bridged the barriers of distance in transportation, communications, business transactions etc. It has equally revolutionized every sector of the lives of individuals, societies and nation states, especially in education, health systems, agriculture and tourism. The list is endless.

\section{Concept of Globalization}

Globalization presents trends that tend to destabilize the prime traditional state, while at the same time bringing out and taking into cognizance the dominant characteristics or tendencies of the world [1]. In the words of Misra [4], globalization is the integration of economies and societies through cross country flows of information, ideas, technologies, goods, services, capital, finance and people. It refers to the process of the intensification of economic, political, social and cultural relations across international boundaries. Globalization is principally aimed at the transcendental homogenization of political and socio economic theory across the globe.

Contributing, Shenkar and Luo [6], posit that globalization is the growing economic interdependencies of countries worldwide through the increasing volume of cross border transaction in goods and services and of international capital flows as well as through the aid and widespread diffusion of technology and information. Its features include integration, change and interaction. Onyekwere, Nwokeukwu and Dike [5], aver that globalization is the process of integration and interaction between diverse groups, governments, systems and nations. Globalization is principally aimed at the homogenization of various sectors (political and socio economic) of the globe. In the past, it was greatly aided by trade. Presently however, globalization has been to a very large extent aided by information and communication technology. Globalization has impacted on the governments, cultures, human beings, political, culture and economic development. Egbon in Akani [2], asserts that;

Globalization has two meanings, as a phenomenon and as a theory of economic development. Within the context of a phenomenon, globalization translates to a greater interdependence among different regions and countries of the world in terms of finance, trade and communication. As a theory of economic development, globalization assumes that a greater level of integration is taking place among different regions of the world and that this integration is having an 
important impact on economic growth and social indicators.

The integration trend associated with globalization is reinforced by the improvement in information communications technology. The knowledge and acquisition of technological know-how becomes a desideration for the understanding of the principles of globalization [2].

\section{Effects of globalization}

Globalization has both positive and negative effect on both individuals and societies. Globalization has brought benefits mostly to developed countries in investments and capital flows, employment generation, culture and organization structure. On a general note, globalization has brought such benefits to both rich and poor nations as increased free trade and communication, increased access to technology, media, educational resources, healthcare and consumer goods.

Most of the negative effects of globalization tilt towards the less developed and poor countries of the world. Such negative effects include increased unemployment, spread of western culture (cultural imperialism) high tariffs on manufactured goods and trade imbalance amongst others.

\section{Concept of Management}

Management as a concept, has no single universally accepted definition. However, what is well known is that management involves;

1. People;

2. Coordination of the efforts of the group, including material resources;

3. Achieving predetermined objectives.

Drucker [3], submits that management involves administering and coordinating resources effectively and efficiently in an effort to achieve the goals of the organization. Daft in Unachukwu [8], maintains that management is the attainment of organizational goals in an effective and efficient manner through planning, organizing, leading and controlling organizational resources. Bhagwan and Bhushan as cited by Sule [7], argues that management is the process of directing and facilitating the work of people organized in formal groups to achieve a desired goal. Bateman and Snell (2004), assert that management is the process of working with people and resources to accomplish organizational goals.

The foregoing postulations are a clear indication that achieving organizational goals is not possible without effective and efficient management. The elements of management as advanced by Henri Fayol (1841-1925) include;
1. Forecast and plan (prevoyance): Examining the future and drawing up a plan of action. The elements of strategy;

2. To organize: Build up the structure, both material and human of the undertaking

3. To command: Maintain the activity among the personnel

4. To coordinate: Binding together, unifying and harmonizing all activity and effort

5. To control: Seeing that everything occurs in conformity with established rules and expressed command.

\section{Education}

All over the world, the importance, indispensability and linkage of education to the development of any society including Enugu State is well known. Education has always been recognized and accepted globally as a key development index to the extent that it is now generally agreed that economic and social development are increasingly driven by the advancement and application of education [9]. Education is therefore the key to the growth and development of any society.

Education is the process through which worthwhile values, beliefs, norms and attitudes of a given society are transferred from the older to the younger generation. It remains an indispensable instrument for social change. In the words of Akani [2], education is an instrument of change which empowers its recipients to be creative and become change agents useful to themselves and the society at large. In highlighting the importance of education, Rousseau avers that;

We are born weak, we need strength, helpless, we need aid, foolish, we need reason. All that we lack at birth all that we need when we come to man's estate is the gift of education. This education comes to us from the education of men, what we gain by our experience of our surrounding is education [2].

Education is a tool for national development and without education there is no society and development. Education is therefore central to the continued existence of any nation because a nation development lies on the quality of its educational system [10]. In similar vein, the Federal Republic of Nigeria (2013), maintains that education remains the most potent instrument for national development. In the light of the foregoing, qualitative and functional education for everyone and especially our future leaders become compelling. 


\section{Secondary Education}

This is education that children receive after primary education as well as before the tertiary stage. The objectives of secondary education as enunciated in the National Policy on Education, FRN (2013:2930), include, amongst others to;

1. Offer diversified, curriculum to cater for the differences in talents, disposition, opportunities and future roles,

2. Provide trained manpower in the applied science, technology and commerce at subprofessional grades,

3. Provide entrepreneurial, technical and vocational job-specific skills for selfreliance, and for agricultural, industrial, commercial and economic development;

4. Inspire students with a desire for selfimprovement and achievement of excellence;

5. Raise morally upright and well-adjusted individuals who think independently and rationally, respect the views and feelings of others and appreciate the dignity of labor.

It has been noted and it is clear that the globalization phenomenon has traversed all sectors of our lives and society, including Enugu state. Enugu state with capital in Enugu is one of the 36 states that make up the Federal Republic of Nigeria. It is located in the South East Zone of the country. The extent to which globalization has impacted on the management of secondary education in the state is uncertain. This is the gap the present study intends to fill.

\section{The Principal}

The Cambridge International Dictionary of English are cited are cited by Babayemi [11] submits that the principal is a person in charge of a school or college for children aged between 11 and 18. In Enugu State and elsewhere, the principal is the head of a secondary school. He is the head of the school organization, the functional and instructional leader of the school.

As far as the secondary school organization is concern, the principal is many things in one. As the executive head, the principal keeps things running in order in the school. He is the chief accounting who carries the blame or praise as far as the success or failure of the school is concerned [12]. All vital records of the school are under his care.

The principal is the change facilitator, the school climate developer as well as the manager of men and materials. All vital decisions in the school, carries his stamp of authority. To succeed as a supervisor the principal must:

1. Be true to his own idea but at same time flexible, loyal, respect the beliefs, rights and dignity of those around him.

2. Be strong willed, consistent and fair in dealing with others.

3. Be open in decision making and respect peoples' opinions on matters affecting the school system.

4. The principal must be prepared for opposition, but should handle opposition without malice.

5. He must be sincere, firm, approachable, ready to help people to solve their problems and maintain a relaxing atmosphere that will encourage, stimulate and inspire people around him to work harmoniously [11].

From the foregoing, the destiny of the school lies in the hands of the principal. His activities, positive or negative goes a long way in defining the future of the staff and students under him.

\section{Statement of the Problem}

Through ICT, the globalization experience has touched peoples' lives around the world in education, health, agriculture, business, and finance. The list continues. In Enugu state, Nigeria, the extent to which globalization has impacted on the management of secondary level of education is uncertain. This is the problem of the present study. This could be put in question form thus; to what extent has globalization impacted on the management of secondary education in Enugu State?

\section{Research Questions}

The following research questions guided the study:

1. To what extent has globalization influenced on the management of secondary education in Enugu state in the area of teaching methods?

2. To what extent has globalization influenced on the management of secondary education in Enugu state in terms of instructional materials utilization?

3. To what extent has globalization influenced the management of secondary education in Enugu State in terms of discipline? 


\section{Hypotheses}

The following null hypotheses tested at .05 level of significance were formulated to guide the study.

1. There is no significance difference between the mean responses of male and female principals on the influenc of globalization on the management of secondary education in terms of teaching methods

2. There is no significant difference between the mean responses of male and female principals on the influence of globalization on the management of secondary education in Enugu state in terms of instructional materials utilization.

3. There is no significant difference between in the mean responses of male and female principals on the influence of globalization on the management of secondary education in Enugu State in the area of discipline.

\section{Method}

Descriptive survey research design was adopted for the study using a researcher developed instrument, tagged: impact of globalization questionnaire (IGQ). The instrument was designed with a four point scale of Very Great Extent (VGE) 4points, Great Extent (GE) 3points, Little Extent (LE) 2points and Very Little Extent (VLE) 1point The study was carried out using all 291 principals in all the 291 public secondary schools in Enugu state. There was no sampling because the population was small and manageable. Of the 291 principals, 82 were females, while 209 were males. The use of principals for the study was as a result of their experience and strategic placing in secondary education administration and management. This places them in a vantage position to respond appropriately to issues pertaining to the impact of globalization on the management of secondary education in Enugu State.

The instrument for data collection was validated by three experts from the Faculty of Education, Enugu State University of Science and Technology (ESUT), Agbani, Enugu State. Two of the experts were from the Department of Educational Management, while the remainder was from the Department of Science and Computer Education (Measurement and
Evaluation Unit). The reliability coefficient of the instrument was determined using Cronbach Alpha. Alpha values for clusters one, two and three yielded $.61, .63$ and .64 respectively, while the overall value yielded .67 , indicating a high reliability of the instrument for the study.

The researcher employed the services of 6 research assistants who handled the distribution and collection of the questionnaire among the respondents. The research assistants were secondary school teachers who were chosen because of their experience in secondary school administration and understanding of the terrain in Enugu State. They were trained in a one-day consultative meeting on the rationale for the study and how to distribute and retrieve the questionnaire from the respondents. The distribution and collection of the questionnaire spanned two weeks because of appointments with those that could not fill and return copies of the questionnaire on the spot.

Of the 82-questionnaire distributed among female principals, 75 were well completed and returned, giving a return rate of $91 \%$. Also, of the 209 questionnarie given out to male principals, 193 were well completed and returned, giving a return rate of $92 \%$. Equally of the 291-questionnaire given out to the whole respondents, 268 were returned, giving a retrieval rate of $92 \%$.

For data analysis and decision rule, any item with mean of 2.50 and above was regarded as great extent, while any mean less than 2.50 was regarded little extent. The mean average was obtained by summing up the values of the four-point scale and dividing the value by the number of the four point scale thus, $\frac{4+3+2+1}{4}=\frac{10}{4} 2.50$

For the hypotheses, when t-calculated is equall to or greater than t-crtical, the null hypothesis was rejected meaning there was significant difference between the mean scores of the respondents. Conversely, when t-calculated was less than t-critical (t-crit), the hypothesis was not rejected indicating there was no significant difference between the mean scores of both the male and female principals.

Table 1 reveals that there was a grandmean of 1.87 for male principals, as well as 1.77 for female principals. This indicates that globalization has impacted to a little extent on the management of secondary education in Enugu State in the area of teaching methods. 
Table 1. Mean scores, grandmean and standard deviation of respondents on the extent to which globalization has impacted on the management of secondary education in terms of teaching methods

\begin{tabular}{|c|c|c|c|c|c|c|c|c|c|c|c|c|c|c|c|}
\hline \multirow[t]{3}{*}{$\mathbf{S} / \mathbf{N}$} & \multirow[t]{3}{*}{ Items } & \multicolumn{7}{|c|}{$N=193$ Male principals } & \multicolumn{7}{|c|}{$\mathrm{N}=75$ Female Principals } \\
\hline & & VGE & GE & LE & VLE & & SD & DEC. & VGE & GE & LE & VLE & & SD & DEC. \\
\hline & & 4 & 3 & 2 & 1 & $\overline{\mathbf{x}}$ & & & 4 & 3 & 2 & 1 & $\bar{x}$ & & \\
\hline & $\begin{array}{l}\text { Extent to which globalization } \\
\text { has impacted on the following } \\
\text { teaching methods in secondary } \\
\text { schools in Enugu state }\end{array}$ & & & & & & & & & & & & & & \\
\hline 1. & Demonstration & 16 & 28 & 41 & 108 & 1.75 & 0.99 & LE & 6 & 11 & 9 & 49 & 1.65 & 1.01 & LE \\
\hline 2. & Lecture method & 10 & 21 & 36 & 126 & 1.56 & 0.88 & $\mathrm{LE}$ & 8 & 10 & 13 & 44 & 1.76 & 1.05 & LE \\
\hline 3. & Presentation method & 33 & 41 & 46 & 73 & 2.18 & 1.12 & LE & - & 13 & 17 & 45 & 1.57 & 0.77 & LE \\
\hline 4. & Discussion method & 29 & 35 & 44 & 85 & 2.04 & 1.11 & LE & 10 & 14 & 16 & 35 & 1.99 & 1.10 & LE \\
\hline 5. & Brainstorming & 19 & 28 & 38 & 108 & 1.78 & 1.03 & $\mathrm{LE}$ & 5 & 12 & 14 & 44 & 1.71 & 0.97 & LE \\
\hline \multirow[t]{2}{*}{6.} & Role play & 22 & 29 & 46 & 96 & 1.88 & 1.05 & LE & 9 & 13 & 15 & 38 & 1.91 & 1.08 & LE \\
\hline & GrandMean \& SD & & & & & 1.87 & 1.03 & LE & & & & & 1.77 & 0.97 & LE \\
\hline
\end{tabular}

Table 2. Mean scores, grandmean and standard deviation of respondents on the extent to which globalization has impacted on the management of secondary education in terms of instructional materials utilization

\begin{tabular}{|c|c|c|c|c|c|c|c|c|c|c|c|c|c|c|c|}
\hline \multirow[t]{3}{*}{$\mathbf{S} / \mathbf{N}$} & \multirow[t]{3}{*}{ Items } & \multicolumn{7}{|c|}{$N=193$ Male principals } & \multicolumn{7}{|c|}{$\mathrm{N}=75$ Female Principals } \\
\hline & & VGE & GE & $\mathbf{L E}$ & VLE & & SD & DEC. & VGE & GE & LE & VLE & & SD & DEC. \\
\hline & & 4 & 3 & 2 & 1 & $\overline{\mathbf{x}}$ & & & 4 & 3 & 2 & 1 & $\overline{\mathrm{x}}$ & & \\
\hline & $\begin{array}{l}\text { Extent to which globalization } \\
\text { has impacted on the following } \\
\text { usage of the instructional } \\
\text { materials in secondary schools } \\
\text { in Enugu State }\end{array}$ & & & & & & & & & & & & & & \\
\hline 7. & Diagrams & 21 & 29 & 38 & 105 & 1.82 & 1.05 & LE & - & 17 & 24 & 34 & 1.77 & 0.80 & LE \\
\hline 8. & Charts & 23 & 21 & 36 & 113 & 1.76 & 1.06 & $\mathrm{LE}$ & 7 & 12 & 19 & 37 & 1.85 & 1.01 & LE \\
\hline 9. & Tables & 17 & 28 & 40 & 108 & 1.76 & 1.00 & LE & 6 & 16 & 20 & 33 & 1.93 & 0.99 & LE \\
\hline 10. & Flow charts & 20 & 31 & 43 & 99 & 1.85 & 1.04 & $\mathrm{LE}$ & - & 11 & 13 & 51 & 1.47 & 0.74 & LE \\
\hline 11. & Graphs & 22 & 28 & 37 & 106 & 1.82 & 1.06 & $\mathrm{LE}$ & - & 9 & 22 & 44 & 1.53 & 0.70 & LE \\
\hline 12. & Worksheet & 15 & 31 & 40 & 107 & 1.76 & 0.99 & LE & 11 & 8 & 16 & 40 & 1.87 & 1.11 & LE \\
\hline \multirow[t]{2}{*}{13.} & Audio/video clips & 18 & 26 & 39 & 110 & 1.75 & 1.01 & $\mathrm{LE}$ & 5 & 10 & 8 & 52 & 1.57 & 0.96 & LE \\
\hline & GrandMean \& SD & & & & & 1.79 & 1.03 & & & & & & 1.71 & 0.90 & LE \\
\hline
\end{tabular}

Table 2 indicates that the grandmean for both male and female principals was 1.79 and 1.71 respectively. This shows that to a little extent, globalization has impacted on the management of secondary education in Enugu State in the area of instructional materials utilization.

Table 3. Mean scores, grandmean and standard deviation of respondents on the extent to which globalization has impacted on the management of secondary education in terms of discipline

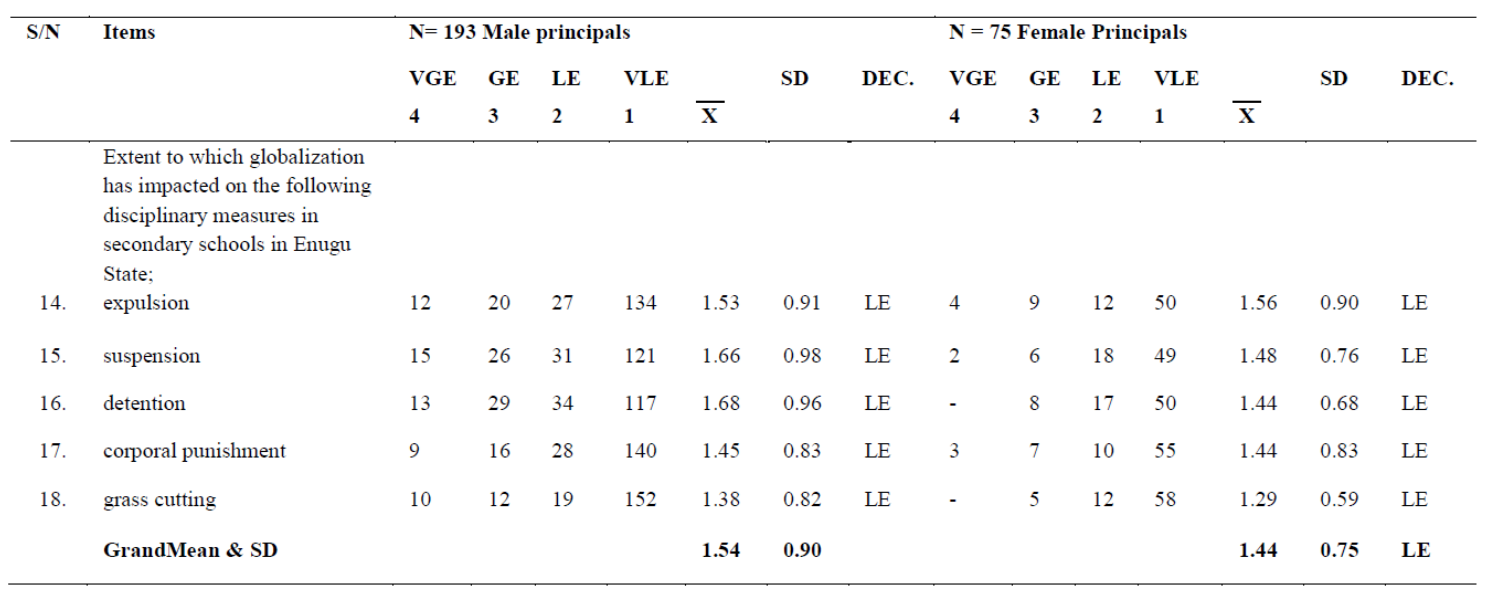


Table 3 indicates that the grandmean for both male and female principals was 1.54 and 1.44 respectively. This shows that to a little extent, globalization has impacted on the management of secondary education in Enugu State in the area of discipline.

Table 4. t-test of significant difference between the mean scores of male and female principals on the impact of globalization on the management of secondary education in terms of teaching methods

\begin{tabular}{llllllll}
\hline Respondents & N & $\overline{\mathbf{X}}$ & SD & Df & t-cal & t-crit & Decision \\
\hline Male principal & 193 & 1.87 & 1.03 & & & & \\
Female principal & 75 & 1.77 & 0.97 & & & & \\
\hline
\end{tabular}

Table 3 indicate that $t$-calculated of 0.74 is less than $\mathrm{t}$-crit of 1.96 at .05 level of significance, the hypotheses was therefore not rejected implying no significant difference between the mean scores of both groups of respondents.

Table 5. t-test of significant difference between the mean scores of male and female principals on the impact of globalization on the management of secondary education in the area of instructional materials utilization

\begin{tabular}{llllllll}
\hline Respondents & $\mathbf{N}$ & $\overline{\mathbf{X}}$ & SD & Df & t-cal & t-crit & Decision \\
\hline Male principal & 193 & 1.79 & 1.03 & & & & \\
Female principal & 75 & 1.71 & 0.90 & & & &
\end{tabular}

Table 4 reveals that the value of t-calculated at .67 is less than the t-crit of 1.96 , at .05 level of significance. The hypotheses was therefore not rejected, implying that there was no significant difference between the mean scores of both groups of respondents.

Table 6. t-test of significant difference in the mean scores of male and female principals on the impact of globalization on the management of secondary education in the area of discipline.

\begin{tabular}{llllllll}
\hline Respondents & $\mathbf{N}$ & $\overline{\mathbf{X}}$ & SD & Df & t-cal & t-crit & Decision \\
\hline Male principal & 193 & 1.54 & 0.90 & & & & \\
Female principal & 75 & 1.44 & 0.75 & & & &
\end{tabular}

Table 3 shows that t-calculated which is 1.00 is less than t-critical which is 1.96 at .05 level of significance. The hypothesis was therefore not rejected implying no significant difference in the mean response scores of both groups of respondents.

\section{Findings of the Study}

1. 1.Globalization has to a little extent influenced the management of secondary education in Enugu State in the areas of teaching methods, instructional materials utilization and discipline.

2. 2.There is no significant difference in the mean responses of both male and female principals on the influence of globalization on the management of secondary education in Enugu State in the areas of teaching methods, instructional materials utilization and discipline.

\section{Discussion and Findings}

Globalization is the integration of economies and societies through the flow of information, ideas, technology, goods, services and people. The study found that globalization has impacted to a little extent on the management of secondary education in Enugu State. This is not good at all. Misra [4], Nwokeukwu and Dike (2017) and Akani [2] all agree that globalization has a lot of benefit to education, culture and commerce. The finding of the present study suggest that the positive impact of globalization is lost to secondary education in Enugu state. It could mean 
that in an age of globalization that has compressed the world into a global village, secondary education in Enugu State is still operating on analogue. This is in line with Onyekwere, Okoriga and Dike [5], who lament the poor state of Nigeria's education. This becomes more worrisome in an age of globalization when access to information has been greatly enhanced.

Akani [2], espouses the indispensable place of education in human growth and development. This education must of course be of the highest quality in order to achieve it purposes. It becomes imperative that secondary education in Enugu state must reap the benefits of globalization to remain competitive.

\section{Recommendations}

The following are recommended:

1. Better funding of secondary education in Enugu state by all stakeholders especially the governments (both state and local).

2. Provision of requisite facilities and equipment in the various Secondary Schools especially ICT equipment, so that the students and the school in general could be better placed to benefit from the positive impact of globalization.

3. Continuous training and retraining of teachers especially in the area of ICT, so as to enhance their capacity to utilize the benefits of globalization in the classroom for the benefit of all.

4. The various governments and school authorities should continuously organize seminars and workshops for students in order to expose the negative effects of globalization. Thus, it will surely have a positive influence on school disciplinary problems.

\section{Conclusion}

Education remains the most potent instrument for the transformation individuals and societies. Secondary education in Enugu state and elsewhere is strategically placed in the achievement of the above mandate. It becomes therefoore compelling that secondary education in Enugu State must be made qualitative and relevant in order to be able to contribute its quota in the enerous task of producing individuals who are ready to contribute for development of society.

\section{Acknowledgements}

The researcher appreciates the research assistants, his wife and children for the sacrifices they endured during the period of this study. He acknowledges the various scholars whose works he cited. The researcher is equally indebted to God for the health and knowledge that made the completion of the study possible.

\section{References}

[1] Adelabu, M. (2006). Globalization and imperatives for change in educational policy making in Nigeria. Paper presented at the 3rd VITTACHI International Conference on Rethinking Educational Change. Ifrane, Morocco. 1st5th July.

[2] Akani, C. (2012). The effect of globalization on Nigerian education. Global Advanced Research Journal of Social Science. 1(5) 92-100.

[3] Drucker, P. (2004). What makes an effective executive? Harvard Business Review. Harvard: Harvard University Press.

[4] Misra, S. (2012). Implications of globalization on education. Romanian Journal for Multidimensional Education. 4(2) 1-18.

[5] Onyekwere, N. Okoringa, N. \& Dike, H. (2017). Impacts of globalization on the educational system of Nigeria. International Journal of Advanced Academic Research. 3(8) 140-147.

[6] Shenkar, O. \& Luo, Y. (2004). International business. New York: John Wiley and Sons.

[7] Sule, S.A. (2016). Management of innovation procedure In C.C. Uchendu \& B.A. Akuegwu (Eds). Educational management: A guide for practitioners. Calabar: University of Calabar press.

[8] Unachukwu, G.O. (2014). Leadership in formal organizations. In G.O. Unachukwu \& P.N. Okorji (Eds). Educational management: A skill building approach. Nimo: Rex Charles and Patrick Limited.

[9] Alabi, R.O. \& Oladejo, M.A. (2016). Towards sustainable funding of Nigerian public universities: The public-private partnership option. Nigerian Journal of Educational Administration and Management (NJEAM). 1(2), 36-50.

[10] Igwe, C.A. (2016). Quality management in the Nigerian secondary school system. Nigerian Journal of Educational Administration and Management (NJEAM). $1(2), 129-136$.

[11] Babayemi, B.A. (2006). Principalship. In J.B. Babalola, A.O. Ayeni, S.O. Adedeji, A.A. Suleman \& M.O. Arikewuyo (Eds) Educational management: Thoughts and practice. Ibadan: Codat publications.

[12] Ajiboye, E.O. (2004). Supervision and discipline in schools. Paper presented at a 3-day orientation workshop for newly appointed secondary school principals in Oyo State. September 14th-16th. 